\title{
THE IMPLEMENTATION AND DEVELOPMENT OF PRODUCTIVE WAQF IN INDONESIA: CASE AT MALANG ISLAMIC HOSPITAL
} Vika Annisa Qurrata ${ }^{1}$, Bagus Shandy Narmaditya ${ }^{2^{*},}$, Linda Seprillina ${ }^{3}$, Nor Ermawati Binti Hussain ${ }^{4}$

\author{
${ }^{1,2,3}$ Faculty of Economics, Universitas Negeri Malang, Indonesia, ${ }^{4}$ Universiti Malaysia Terengganu, Malaysia.
} Email: "bagus.shandy.fe@um.ac.id

Article History: Received on $12^{\text {th }}$ July 2019, Revised on $30^{\text {th }}$ August 2019, Published on $23^{\text {rd }}$ September 2019

\begin{abstract}
Purpose of the study: This study intended to analysis the implementation and development of productive waqf in Malang, Indonesia. In addition, it addressed to understand the operational management of productive waqf Islamic hospital in Malang.

Methodology: The research applied a qualitative method in order to comprehensively understand the existing phenomenon. The qualitative data analysis model used in this research followed the process of data reduction, display data, and verification by Miles \& Huberman (1984). Purposively, the sample of the research was in an Islamic hospital in Malang considering various relevant reasons. The data were collected through focus group discussion between stakeholders including waqf recipient (Mauquf'Alaih), waqf management (Nazhir) and researches.
\end{abstract}

Main Findings: The findings showed that the implementation of productive waqf has shown favorable outcomes in attaining local community's needs that lead to the economic welfare of communities. The management model of productive a waqf is divided into a certain considered portion for business development, Mauquf'Alaih, and Nazhir.

Applications of this study: In its development, productive waqf management should consider potential factors such as human resources and community awareness.

Novelty/Originality of this study: The research provides insight into the nature of the productive waqf model as an attempt to enhance economic welfare.

Keywords: productive waqf, social welfare, human well-being, management model, cash waqf.

\section{INTRODUCTION}

For Moslem, waqf plays an important role in developing religiosity and their relationship to society. There are two paradigms in managing waqf including ideology paradigm and socio-economic paradigm. The ideology paradigm focuses on everything that culminates in the belief in God's Perseverance must be accompanied by the awareness of the realization of social justice. Meanwhile, in the context of the socio-economic paradigm, waqf alternatively contributes to problemsolver in economic issues occurred in society (Shaikh et al., 2017). In other word, waqf provides a solution for economic inequality problems in society (Amuda, 2013; Shaikh et al., 2017).

From macroeconomic perspectives, waqf instruments can be included in fiscal instruments as sources of government revenues and expenditures (Budiman \& Kusuma, 2011). It also could also be included in the investment category when the expenditure for waqf was not managed by the government instead of private-owned business entities. Therefore, national income is influenced by household consumption, investment expenditure by business entities, government expenditure, and export. Investment is a function of the interest rate and expenditure for cash waqf. While government expenditure is a function of productive endowments and tax revenues. Thus, changes in investment or government spending will also change the position of national income. Increasing investment or increasing government spending will affect national income. The result is an increase in national income which is one step forward towards equitable development.

In Indonesia context, waqf management caught comprehensive attention from the Government. It was initiated by an issuance the Government Law No. 28 of 1977 about waqf for owned land. However, it not covers yet management for productive waqf. Moreover, the Indonesian government enhances the law related management productive waqf by issuing Law No. 41 of 2004 and No. 42 of 2006. Indonesia experienced a development phase of waqf(Sudirman, 2014; Munir, 2013). First, the traditional waqf which is placed waqf as the main issue in religion so that the existence of waqf has not provided a broader social contribution because it is only for consumptive interests. Second, the semi-professional period, in which the pattern of empowering waqf productive began. It was proven several activities such as the construction of mosques that were strategically located to add buildings to meetings, began to develop waqf empowerment for agriculture, establishing small businesses, even though the pattern management is still traditional. Lastly is professional period which shows an empowering community productively. A professional aspect includes management, human resource, cooperation pattern, and the form of waqf itself like money and securities.

In general, waqf is provided in the form of land, mosques, school building, and the Islamic boarding school (Nufzatutsaniah, 2018). However, the community needs cash money in enlarging its business that makes improving community welfare. Previous studies by Al-Arif (2012); Syafiq (2016) and Hassan, Abdul-Rahman, \&Yazid (2018)revealed that waqf in the form of cash money provided an alternative way in reducing poverty alleviation. Cash 
waqf is pooled as waqf asset and it must be managed wisely until it grows and generates income for social welfare (Khamis\&Salleh, 2018; Saifuddin et al., 2014). It is reasonable because money is a flexible commodity that has bigger value for many purposes. Economically, cash money waqf model contributes to wide aspects in society compared to traditional management model of waqf.

Numerous prior studies related to waqf management model had conducted in many countries. However, in fact, there are few studies that focus on waqf productive particularly on implementation cash waqf management in Indonesia (Khamis\&Shalleh, 2018; Said \&Amiruddin, 2019; Mokhtar, Sidin, \&AbdRazak, 2015;Thoarlim, Rahman, \&Yanya, 2017). For instance, Khamis \& Shalleh (2018) conducted research on cash waqf management in Malaysia. Indeed, Mokhtar, Sidin, \& Abd Razak, (2015) were carried out the implementation of productive waqf and its challenges in Malaysia. While Thoarlim, Rahman, \&Yanya (2017) concerned on management of productive waqf in Bangladesh. Therefore the study provides the implementation of productive waqf and its development in certain areas in Indonesia.

\section{METHODOLOGY}

This research applied a descriptive qualitative approach. In this method, the researchers addressed to provide comprehensively about productive waqf management. This research was conducted in Unisma Hospital in Malang considering several important issues and representations of the study. The data were divided into two namely primary and secondary data. The primary data was gathered directly in the field through several ways such as providing questionnaires and engaging by focus group discussion consisting of structured-interview and open-interview. The questionnaires are related to public perception about productive waqf management, impact on the society, and the advantages and drawbacks of productive waqf. Meanwhile, the secondary data was obtained from relevant literature on the website of Unisma hospital, the government law on waqf and other relevant resources. Furthermore, the data were analyzed accordingly using Miles \& Huberman (1984) model following several steps namely the process of data reduction, data display, and verification.

\section{DISCUSSION / ANALYSIS}

\section{The model of productive waqf management in Malang}

According to Kahf (1998), there are various modes of productive waqf management such as istibdal, hukr, ijaratayn, venture philanthropy of waqf model (VPWM), a value-based capital model of waqf (VBCMW), and social enterprise waqf fund model (SEWF). Most of many waqf institutions are using traditional modes for the development of waqf assets and funds in example are istibdal, hukr, ijaratayn. Therefore, it is expected that modern models of waqf management for instance venture philanthropy of waqf model (VPWM), the value-based capital model of waqf (VBCMW), and social enterprise waqf fund model (SEWF). In Indonesia, there have been several hospitals funded from productive waqf and their management needs to be improved by knowing which model is eligible for them, including the construction of VIP classrooms at Malang Islamic Hospital, East Java. The Malang Islamic Hospital is under the management of Malang Islamic University Foundation (UNISMA) whilst the occupying land owned by Al-Ma'arif and MAN 1 Malang covering 2 H. It is located on Jl. MT. Haryono 139 Malang or about $5 \mathrm{~km}$ from the center of Malang. The Malang Islamic hospital received approximately 2 Billion Rupiah empowerment of productive waqf. The determination of the assistance fund was ratified through a Decree of the Director-General of Islamic Community Guidance No. Dj.II /243/2006 (Departemen Agama, 2008).

Table 1. The percentage of profit usage from business

\begin{tabular}{llll}
\hline Percentage & \multicolumn{1}{c}{$\mathbf{7 0 \%}$} & \multicolumn{1}{c}{$\mathbf{2 0 \%}$} & \multicolumn{1}{c}{ Mauquf'Alaih } \\
\hline Information & \multicolumn{1}{c}{ Business Development } & Nazhir \\
\hline Purposes & $\bullet$ Additional VIP rooms & $\bullet$ Education & $\bullet$ Income \\
& $\bullet$ Establishment a minimarket & $\bullet$ Economic well-being & $\bullet$ Management fee \\
& $\bullet$ Culinary business & $\bullet$ Additional income & $\bullet$ Maintenance cost \\
& $\bullet$ Syaria homestay & & \\
\hline
\end{tabular}

Table 1 provides information about the using of received profit from the business. In its implementation, the profit from the business was addressed to several purposes such as about 70 percent for business development, 20 percent for mauquf'Alaih (a person or organization to receive waqf) and 10 percent for Nazhir (people or organization who manage of waqf). In more detail, the development of the business can be shown from the enhancement of four addition VIP rooms, establishment of minimarkets in more than five areas in Malang, culinary business in the location and provides the sharia homestay in the next future.

On the other hand, approximately 20 percent of profit was provided for Mauquf'alaih consisting of cleaners at mosques, imam mosques, sermons in mosques and diniyah teachers. The addressed funding for those people has several reasons. For many indigent people, had covered by the government using several models such as national health insurance, scholarship and so forth. However, in fact, there is no people and organization helped and prospered Mauquf'alaih. Therefore, this program is reasonable and matter to provide well-being for Mauquf'alaih. 
The rest of the total profit or approximately 10 percent is addressed to Nazhir as a professional person or organization in managing waqf appropriately. In fact, in its implementation, managing a productive waqf cannot be separated from Nazhir. They play a significant role in determining success or failure in managing waqf. Nazhir was the main manager of waqf, taking responsibility that was not easy to be conducted. It ranges from endowments to Badan Wakaf Indonesia (BWI), managing endowments to generate, allocate benefits, and make reports to publish the development of waqf. However, in managing a productive waqf should be supported by supervisions in both administrative and financial supervision (Bank Indonesia, 2018).

Furthermore, this model of waqf management nearly similar to Malaysia. In Malaysia, waqf properties are mostly developed for a common purpose for instance, the building of mosques, religious schools and social welfare (Harun et al., 2012). Waqf Institution in Malaysia mostly is led by a chief executive officer (CEO), who is responsible to report to the Waqf Institution A's board of directors (BOD). The BOD consists of 11 members from various backgrounds such as accounting, business, religious, legal, architecture, and land. The BOD is responsible for governing and implementing all waqf projects and activities undertaken by Waqf Institution A. The BOD is also responsible for the waqf fund collection, which is given by the public at large (Kamaruddin et al., 2018). In order to boost waqf collection, Waqf Institution in Malaysia has also collaborated with Islamic Bank as its strategic partner. A cash waqf scheme has been successfully launched by waqf and Bank to gather funds from the public. A Joint Management Committee (JMC) was established between the Islamic Bank and Waqf Institution to manage the Cash Waqf fund. The JMC is answerable to the Waqf Council, which reports directly to the state ruler.

The JMC is responsible for channeling collected waqf funds for waqf projects, helping the waqf recipients, particularly in education and health. It also invests a portion of the waqf profits. The investment of waqf funds is managed by the Islamic Bank. 25 percent of investment returns are allocated to Waqf Institution whereas another 75 percent is given to the JMC to be re-allocated to appropriate waqf activities/programs. According to Kamaruddin et al. (2018) findings, this model has not applied in Malang's waqf institution yet. However, it can be considered to use in Malang's waqf institution due to the fact that it is not only easier to develop the institution but also will give more transparency in the institution's management.

\section{Operational Management of Productive Waqf in Unisma}

In its development, Indonesia has experienced three big phases in managing waqf including traditional, semi-professional, and professional. In traditional perspectives, waqf does not provide a social contribution because it is only for consumptive reasons. Meanwhile, in the semi-professional phase, it has started to develop model waqf management productively. However, in fact, the implementation is more likely intended to build a mosque and a building for meeting purposes in a village or region. In its development, the usage of waqf is addressed for wider purposes such as for funding in farming, establishing a small business and so forth.

In the professional period, waqf management aims to empower the local community that is managed productively. The professionalism in this matter related to several aspects such as management, human resources, cooperation model, cash waqf and other securities form. In addition, the professionalism era is supported by Indonesian government in providing government law which focusing on waqf. These matters are addressed to enhance community welfare for several purposes such as education, health and social.

Another question proposed is related to how operational management becomes a productive waqf with many businesses. Respondent mentioned that operational management in UNISMA Hospital focusses on qualified and fresh graduate human resources, particularly in administration and accounting positions. Based on the fact that hiring a professional is always an expensive business proposition since they are in a better position to ask for higher salaries, perks, and benefits. Also since they are experienced, the prospect of hiring experienced professionals is enticing to employers, for the value addition in terms of knowledge, skills, profits, and performance.

The starting salary for fresh graduates is much less than experienced ones. It is a possible reason because it will cut off the management cost. Management will get not only financial profit but also bright ideas that could give some more values to the performance and management's culture. Nonetheless, in Singapore, funding problems can be solved by raises funds for rebuilding and renovation in several ways; internal funding through Baitulmal fund; long lease (hukr), sale of existing properties, and external financing (Karim, 2010). Furthermore, another way to increase funds can be through from sukuk scheme. In the beginning, wakif and nazhir use a joint venture agreement (musharaka) to contrive commercial complex. Next, wakif will receive certificates (sukuk), meanwhile nazir contributes land and some capital.

\section{Obstacles in Managing Productive Waqf}

Every business activity faces several obstacles that should be managed properly. In this study, it can be found some issues related to waqf productive management such as lack of funds, lack of knowledge and the existence of suspicion. For this first problem can be overcome due to many Islamic banks are ready to back up funds to help in developing productive waqf projects at the UNISMA Hospital. However, from Nazhir and its managers, they said that as much as possible they prefer to use their own funding rather than receive a loan from a bank. That is the reason behind their operational management, especially in their human resources, is very good and neatly arranged. 
There is still a connection regarding the lack of funds, if a business experiences shortage condition approximately 10-20 percent, it might be considered by the manager when there is a development plan. However, in the other case, when the business needs additional funding higher than 50 percent, the manager does not dare to take risks. In other words, the first business development plan will be put forward. Next, the second problem is about licensing. Where the permits they administer in the Pledge Act of Endowments have not been resolved until the present. Therefore, in running a business development they think for several times because they do not want to take possibility risks. For this reason, they will wait until the licensing is finished then they dare to step up to do a lot of development. It is because the manager does not want to have a dispute with the heirs in the future.

In addition, there are also obstacles faced by productive waqf managers, namely the lack of knowledge of the surrounding community about productive waqf. Indeed, there are people who know that their business is in the form of productive endowments, but there are still not many people who know about the advantages or disadvantages of the business, and finally many of the consumers only use their services. This may be affected by the community that cannot distinguish between non-productive waqf and productive waqf. At the time, the public knows about waqf only in the form of immovable objects such as land used for prayer rooms, mosques or schools. There are also other obstacles, namely the existence of suspicion when the business progresses. Labor limitations are also the problems they face. As well as market conditions or market share that sometimes experience quiet. Due to the fact that it is better to running and handling business by every person who has experienced it. This circumstance is similar in Malaysia due to the fact that they still facing poor management of waqf assets from the aspect of documentation. This is based on the fact that the storage of the relevant data is still remained by using manual system (Hasan et al., 2015).

\section{ACKNOWLEDGEMENT}

This research was funded through a grant by the Directorat of Research and Community Services (LPPM) Universitas Negeri Malang.

\section{REFERENCES}

1. Amuda, Y. J. (2013). Empowerment of Nigerian muslim households through waqf, zakat, sadaqat and public funding. International Journal of Trade, Economics and Finance, 4(6), 419-424. https://doi.org/10.7763/IJTEF.2013.V4.329

2. Al-Arif, M. N. R. (2012). Wakaf uang dan pengaruhnya terhadap program pengentasan kemiskinan di Indonesia. Jurnal Indo-Islamika, 2(1), 17-29.

3. Bank Indonesia. (2018). Core Principles for Effective Waqf Operation and Supervision. International Working Group on Waqf Core Principles. Retrieved from https://www.bi.go.id/id/ekonomi-dan-keuangansyariah/materi/Bahan-Sosialisasi/Documents/Waqf-Core-Principles-2018.pdf.

4. Budiman, M. A., \& Kusuma, D. B. W. (2011). The economic significance of waqf: a macro perspective. In 8th International Conference on Tawhidi Methodology Applied to Microenterprise Development. pp. 2-17.

5. Harun, R., Isa, Z. M., \& Ali, N.(2012). Preliminary Findings on Waqf Management Practices among Selected Muslim Countries. 2012 International Conference on Economics Marketing and Management, Hong Kong, China, 5-7 January.

6. Hasan, Z. A., Othman, A., Ibrahim, K., Shah, M. A. M. M., \& Noor, A. H. M. (2015). Management of Waqf in Malaysia. International Journal of Nusantara Islam, 3(1), 59-68. https://doi.org/10.15575/ijni.v3i1.412

7. Hassan, N., Abdul-Rahman, A., \& Yazid, Z. (2018). Developing a new framework of waqf management. International Journal of Academic Research in Business and Social Sciences, 8(2), $287-305$. https://doi.org/10.6007/IJARBSS/v8-i2/3872

8. Kamaruddin, M. I. H., Masruki, R., \& Hanefah, M. M. (2018). Management Waqf Practices: Case Study in A Malaysian Waqf Institution. World Journal of Social Sciences, 8(3), 1-12.

9. Kahf, M. (1998), Financing the Development of Awqaf Property, Seminar on Development of Awqaf by Islamic Research and Training Institute (IRTI), Kuala Lumpur.

10. Karim, S. A. (2010). Contemporary Shariah Compliance Structuring for the Development and Management of Waqf Assets in Singapore. Kyoto Bulletin of Islamic Area Studies 3(2), 143-164.

11. Khamis, S. R., \&Salleh, M. C. M. (2018). Study on The Efficiency of Cash Waqf Management In Malaysia. Journal of Islamic Monetary Economics and Finance, 4(1), 61-84. https://doi.org/10.21098/jimf.v4i1.732

12. Miles, M. B.,\& Huberman, A. M. (1984). Qualitative Data Analysis: A Sourcebook of New. Methods. California; SAGE publications Inc.

13. Mokhtar, F. M., Sidin, E. M., \& Abd Razak, D. (2015). Operation of cash waqf in Malaysia and its limitations. Journal of Islamic Economics, Banking and Finance, 113(3158), 1-15.

14. Munir, Z. A. (2013). Revitalisasi Manajemen Wakaf Sebagai Penggerak Ekonomi Masyarakat. Journal de Jure, 5(2), 162-171. https://doi.org/10.18860/j-fsh.v5i2.3007

15. Nufzatutsaniah. (2018). Pengaruh Wakaf Produktif Terhadap Peningkatan Ekonomi Pesantren Darunnajah Jakarta. Jurnal Ilmiah Manajemen Forkamma, 1(3), 72-84. https://doi.org/10.32493/frkm.v1i3.2550

16. Said, S., \& Amiruddin, A. M. A. (2019). Wakaf Tunai dan Pemberdayaan Ekonomi Masyarakat. Al-Mashrafiyah: Jurnal Ekonomi, Keuangan, dan Perbankan Syariah, 3(1), 43-55. 
17. Saifuddin, F., Kayadibi, S., Polat, R., Fidan, Y., \& Kayadibi, O. (2014). The Role of Cash Waqf in Poverty Alleviation: Case of Malaysia. In Kuala Lumpur International Business, Economics and Law Conference 4 (KLIBEL4). Kuala Lumpur.

18. Shaikh, S. A., Ismail, A. G., \& Mohd Shafiai, M. H. (2017). Application of waqf for social and development finance. ISRA International Journal of Islamic Finance, 9(1), 5-14. https://doi.org/10.1108/IJIF-07-2017-002

19. Sudirman, S. (2014). Regulasi Wakaf Di Indonesia Pasca Kemerdekaan Ditinjau Dari Statute Approach. Journal de Jure, 6(2), 190-203. https://doi.org/10.18860/j-fsh.v6i2.3228

20. Syafiq, A. (2016). Wakaf Tunai Untuk Pemberdayaan Usaha Kecil. ZISWAF: Jurnal Zakat dan Wakaf, 1(2), 1-25.

21. Thoarlim, A., Rahman, M., \& Yanya, A. (2017). Cash waqf in Bangladesh and the need for innovative approach towards Waqf: Lessons from selected countries. International Journal of Academic Research in Business and Social Sciences, 7(4), 151-169. https://doi.org/10.6007/IJARBSS/v7-i4/2795 